\title{
Integrated Weed Management in Aerobic Rice (Oryza sativa L.)
}

\author{
Vaishali Yadav*, R.K. Tiwari, Punit Tiwari and Jyoti Tiwari \\ Department of Agronomy, JNKVV, College of Agriculture, Rewa-486001, \\ Madhya Pradesh, India \\ *Corresponding author
}

\begin{tabular}{|c|c|}
\hline & $\boldsymbol{\Gamma}$ \\
\hline & \multirow{5}{*}{$\begin{array}{l}\text { A field experiment was conducted in Kharif season of } 2014 \text { at, J.N.K.V.V. College of } \\
\text { Agriculture, Instructional Farm, Rewa (M.P.) under All India Coordinated Rice } \\
\text { Improvement Project to study- "Integrated Weed Management in Aerobic Rice (Oryza } \\
\text { sativa L.)". The treatments comprised ten weed control methods which were laid out in } \\
\text { randomized block design with three replications. Among the grassy weeds, Echinochloa } \\
\text { species (annuals), Cynodon dactylon (perennials) and Cyperus rotundus (sedges) were the } \\
\text { most dominating weeds. Among the broad-leaved weeds, Digeria arvensis, Anagalis } \\
\text { arvensis, Launea asplanifolia, Euphorbia hirta, Eclipta alba, Phylanthus niruri and } \\
\text { Celosia argentia (annuals) were the dominant weed species. The study reveals that weed } \\
\text { control in aerobic rice by need based hand weeding (twice) treatment } \mathrm{T}_{9} \text { appeared to be } \\
\text { more effective for getting higher production. However, looking to the labour problem } \\
\text { treatment } \mathrm{T}_{1}\left(\text { Pendimethalin @ } 1.00 \mathrm{~kg} \text { a.i./ha }+ \text { Bispyribac sodium @ } 35 \text { g.a.i/ha) and } \mathrm{T}_{5}\right. \\
\text { (Butachlor @ } 1.5 \mathrm{~kg} \text { a.i./ha }+ \text { Bispyribac sodium @ } 35 \text { g.a.i/ha) may be the best substitute } \\
\text { of hand weeding twice from economic point of view. Among the weed control treatments, } \\
\left.\text { the need based hand weeding treatment ( } \mathrm{T}_{9}\right) \text { and application of Butachlor }(50 \mathrm{EC})+ \\
\text { Bispyribac sodium ( } 10 \% \mathrm{SC})\left(\mathrm{T}_{5}\right) \text { resulted in significantly higher grain yield of } 5406.079 \\
\text { and } 4946.93 \mathrm{~kg} / \mathrm{ha} \text { respectively. In aerobic rice, the WCE was recorded up to } 92.44 \% \text { in } \\
\text { case of need based hand weeding treatment. Amongst the weed control treatments, } \\
\text { application of Butachlor }(50 \mathrm{EC})+\text { Bispyribac sodium }(10 \% \mathrm{SC})\left(\mathrm{T}_{5}\right) \text { treatment gave the } \\
\text { maximum net income (Rs.56135/ha) and B: C ratio }(3.45) \text {. }\end{array}$} \\
\hline $\begin{array}{l}\text { Rice, Integrated } \\
\text { weed management, } \\
\text { Weed growth, } \\
\text { Weed control } \\
\text { efficiency, Yield }\end{array}$ & \\
\hline Article Info & \\
\hline & \\
\hline & \\
\hline
\end{tabular}

\section{Introduction}

Rice (Oryza sativa L.) is a principal source of food for more than half of the world population, and more than $90 \%$ of rice worldwide is grown and consumed in Asia. Globally rice is grown in more than 150 Mha area. India and China together hold about half the world's rice area and more than $60 \%$ people are rice eaters. Among the rice growing countries in the world, India has the largest area under rice crop and ranks second in production next to China. Rice contributes $43 \%$ of total food grain production and $46 \%$ of the total cereal production of the country, and plays a vital role in the national food grain supply. In India rice is cultivated in an area of about 43.8 Mha with the production of 105.24 Mt. during 2012-13 compared to $104.32 \mathrm{Mt}$ in 2011-2012 crop year (July-June). The 
increase in production is more than 5 folds from 20.6 Mt in 1950-51 to 105.24 Mt in 2012-2013. It is the most important crop of Vindhya region of Madhya Pradesh and is sown with different methods under upland and low land conditions.

Rice production and food security largely depend on the irrigated lowland rice system, whose sustainability is threatened by fresh water scarcity, water pollution and competition for water use (Guerra et al., 1998). Future predications on water scarcity limiting agricultural production have estimated that by 2025 about 2 Mha of Asia's irrigated rice fields will suffer from water shortage in the dry season especially since flood-irrigated rice uses more than $45 \%$ of $90 \%$ of total freshwater used for agricultural purposes (Bouman, 2001; Bouman et al., 2005). Hence, the major challenges are to produce more rice, increase water productivity and reduce water input in the fields (Bouman et al., 2001).

Water shortage is becoming severe in many rice-growing areas in the country. Aerobic rice is grown like an upland crop in soil which is not puddled and non-flooded aerobic soil with the support of external inputs like supplementary irrigation, manures and fertilizers etc through which 30 - 50 per cent of water can be saved. However, weeds are a major constraint to direct seeded rice (DSR) production. Since the crop is sown in nonpuddled, unflooded soil in aerobic rice, the weeds and rice germinate simultaneously. The crop-weed competition increases due to the absence of the size differential between the crop and the weeds and the suppressive effect of standing water on weed growth at crop establishment. In aerobic rice, weeds cause yield loss to an extent of 50-100\% (Mishra and Singh, 2007). In such conditions integrated weed management offers most practical and cost effective means of reducing weed competitions. Herbicides are used to control weeds in DSR, but because of concerns about the evolution of herbicide resistance and a scarcity of new and effective herbicides, there is a need to integrate other weed management strategies with herbicide use. In addition, because of the variability in the growth habit of weeds, any single method of weed control cannot provide effective and season-long control in DSR. Various weed management approaches need to be integrated to achieve effective, sustainable, and longterm weed control in DSR. These approaches may include tillage systems; the use of crop residue; weed-competitive cultivars with highyield potential; appropriate water depth and duration; appropriate agronomic practices; manual or mechanical weeding; and appropriate herbicide timing, rotation, and combination. None of the control measures in single can provide acceptable levels of weed control, and therefore, if various components are integrated in a logical sequence, considerable advances in weed management can be accomplished (Swanton and Weise, 1991). Adoption of IWM approach for sustainable rice production has been advocated by many researchers (Azmi and Baki, 2002; Sunil et al., 2010; Jayadeva et al., 2011).

\section{Materials and Methods}

The experiment was conducted under All India Coordinated Research Project (AICRP) on Rice, at the JNKVV Agriculture College Farm, Rewa (M.P.) during kharif season 201415 to study- "Integrated Weed Management in Aerobic Rice (Oryza sativa L.)". Rewa is situated in North Eastern part of Madhya Pradesh at $24^{\circ} 30^{\prime}$ North latitude, $81^{\circ} 15^{\prime}$ 'East longitude and 365.7 meters above mean sea level. It has sub-tropical climate with hot and dry summer and cold winters which are the main features of the region. The selected site represents the major upland rice growing area 
of the region. The topography of the soil was fairly uniform. The soil of the experimental field was clay-silty having $\mathrm{pH} 6.50$, EC 0.42 $\mathrm{dS} / \mathrm{m}$, O.C. $0.60 \%$, available N $234 \mathrm{~kg} / \mathrm{ha}$, available $\mathrm{P}_{2} \mathrm{O}_{5} 18 \mathrm{~kg} / \mathrm{ha}$ and available $\mathrm{K}_{2} \mathrm{O}$ $314 \mathrm{~kg} / \mathrm{ha}$.

The total rainfall received during July to November, 2014 was $814.2 \mathrm{~mm}$. The treatments comprised ten weed control methods, they are Pendimethalin (30 EC) + Bispyribac sodium (10\%SC) $\left(\mathrm{T}_{1)}\right.$, Pendimethalin (30 EC) + 2,4-D (SS) (80WP) $\left(\mathrm{T}_{2}\right)$, Pendimethalin (30 EC) + Straw mulching $\left(\mathrm{T}_{3}\right)$, Pendimethalin (30 EC) + (Chlorimuron $10 \% \mathrm{WP}+$ Metsulfuronmethyl 10\% WP) $\left(\mathrm{T}_{4}\right)$, Butachlor (50EC) + Bispyribac sodium (10\%SC) $\left(\mathrm{T}_{5}\right)$, Butachlor (50EC) + 2,4-D (SS) (80WP) $\left(\mathrm{T}_{6}\right)$, Butachlor (50EC) + Straw mulching $\left(\mathrm{T}_{7}\right)$, Mechanical weeding/weeders $\left(\mathrm{T}_{8}\right)$, Need based hand weeding $\left(\mathrm{T}_{9}\right)$ and Unweeded control $\left(\mathrm{T}_{10}\right)$ which are laid out in randomized block design with three replications.. The rice variety PS-3 was line sown under aerobic condition keeping seed rate $30 \mathrm{~kg} / \mathrm{ha}$ and distances between rows 20 $\mathrm{cm}$. A uniform fertilizer dose of NPK as 100:60:40 $\mathrm{kg} / \mathrm{ha}$ was applied in each treatment. The crop was grown as per recommended package of practices.

The quantity of different herbicides was determined as per treatments according to active ingredient present in the commercial products. Under weed free plot two hand weeding were done, the first hand weeding was done at 20 days and second weeding was done at 45 DAS with the help of khurpi. The observation on population of major weeds viz. Echinochloa crusgalli and other associated weeds were recorded at 60 days after sowing by quadrate count method. The quadrate of $0.25 \mathrm{~m}^{2}$ was randomly selected at four places in each plot by fixing wooden sticks. The weed biomass from different plots under all the treatment was recorded only at harvesting time of crop. The associated weeds were collected randomly with $0.25 \mathrm{~m}^{2}$ quadrate from three places in each plot. The weeds were first sun dried and thereafter kept in paper bags and dried in oven at $60^{\circ} \mathrm{C}$ for 24 hours and dry weight was achieved later. On the data on weed biomass was transformed and expressed in $\mathrm{g} / \mathrm{m}^{2}$.

\section{Results and Discussion}

\section{Effects on weeds}

In the experimental field, there were three dominant grassy weeds viz. Echinochloa species, Parthenium hysterophorus, Cynodon dactylon and Cyperus rotundus. There were seven broad-leaved weeds i.e. Digeria arvensis, Anagalis arvensis, Launea asplanifolia, Euphorbia hirta, Eclipta alba, Phylanthus niruri and Celosia argentia (annuals) were the dominant weed species. The data on existence of the weeds $/ \mathrm{m}^{2}$ recorded before and after treatment application are mentioned in the Table 1.

The total weeds $/ \mathrm{m}^{2}$ was significantly higher under unweeded control treatment $\left(\mathrm{T}_{10}\right)$ before and after applied treatments i.e. 526.00 and $549.67 / \mathrm{m}^{2}$, respectively. All the weed control treatments $\left(T_{1}\right.$ to $\left.T_{10}\right)$ resulted in significant reduction in weeds $/ \mathrm{m}^{2}$. HW twice in $\mathrm{T}_{9}$ resulted in least number of weeds $\left(11.00 / \mathrm{m}^{2}\right)$. This was followed by treatments having herbicide combination $\left(\mathrm{T}_{1}\right.$ and $\left.\mathrm{T}_{5}\right)$. The weed control upto the same extent was also observed in $\mathrm{T}_{3}$ and $\mathrm{T}_{7}$ treatments having straw mulching with Pendimethalin and Butachlor at 1.00 and $1.5 \mathrm{~kg}$ a.i./ha respectively. This was followed by $\mathrm{T}_{2}, \mathrm{~T}_{4}, \mathrm{~T}_{6}$ and $\mathrm{T}_{8}$.

The dry weight of weeds $/ \mathrm{m}^{2}$ in various treatments was recorded according to their total number $/ \mathrm{m}^{2}$. Unweeded control treatment $\left(\mathrm{T}_{10}\right)$ recorded the maximum dry weight $\left(228.77 / \mathrm{m}^{2}\right)$. All the weed control treatments 
$\left(T_{1}\right.$ to $\left.T_{8}\right)$ recorded significantly lower dry weight of weeds (zero to $20.83 \mathrm{~g} / \mathrm{m}^{2}$ ) after treatment application.

The WCE was up to $92.44 \%$ in need based HW $\left(\mathrm{T}_{9}\right)$ treatment. This was followed by $\mathrm{T}_{1}$, $\mathrm{T}_{2}, \mathrm{~T}_{4}, \mathrm{~T}_{5}$ and $\mathrm{T}_{6}$ treatments having herbicidal treatments of weed control (83.53 to $90.15 \%$ ). Herbicidal treatments along with straw mulching recorded $81.28 \%\left(\mathrm{~T}_{3}\right)$ and $80.14 \%$ $\left(\mathrm{T}_{7}\right) \mathrm{WCE}$.
The weed index was found significantly highest $(44.82 \%)$ under unweeded control $\left(\mathrm{T}_{10}\right)$ over the remaining treatments. On the other hand, weed index was least in need based $\mathrm{HW}\left(\mathrm{T}_{9}\right)$ treatment.

This was followed by $\mathrm{T}_{5}$ having Butachlor @ $1.5 \mathrm{~kg}$ a.i./ha + Bispyribac sodium @ 35 g.a.i/ha $(8.35 \%)$ and then $\mathrm{T}_{1}$ having Pendimethalin@1.00 kg a.i./ha + Bispyribac sodium@ 35 g.a.i/ha (10.59\%).

Table.1 Weed studies in aerobic rice as influenced by weed control treatments

\begin{tabular}{|c|c|c|c|c|c|c|}
\hline \multirow[t]{2}{*}{$\begin{array}{l}\text { Tr. } \\
\text { No. }\end{array}$} & \multirow[t]{2}{*}{ Treatments } & \multicolumn{2}{|c|}{$\begin{array}{l}\text { Total number of } \\
\text { weeds } / \mathrm{m}^{2}\end{array}$} & \multirow{2}{*}{$\begin{array}{l}\text { Dry weight } \\
\text { of weeds } \\
\left(\mathrm{g} / \mathrm{m}^{2}\right)\end{array}$} & \multirow{2}{*}{$\begin{array}{c}\text { Weed } \\
\text { control } \\
\text { efficiency } \\
(\%)\end{array}$} & \multirow{2}{*}{$\begin{array}{l}\text { Weed } \\
\text { index } \\
(\%)\end{array}$} \\
\hline & & Before & After & & & \\
\hline $\mathrm{T}_{1}$ & $\begin{array}{c}\text { Pendimethalin }(30 \mathrm{EC})+ \\
\text { Bispyribac sodium }(10 \% \mathrm{SC})\end{array}$ & 283.33 & 17.33 & 27.71 & 87.84 & 10.59 \\
\hline $\mathrm{T}_{2}$ & $\begin{array}{c}\text { Pendimethalin }(30 \mathrm{EC})+2,4-\mathrm{D} \\
\text { (SS) }(80 \mathrm{WP})\end{array}$ & 295.00 & 28.00 & 37.60 & 83.53 & 12.42 \\
\hline $\mathrm{T}_{3}$ & $\begin{array}{c}\text { Pendimethalin }(30 \mathrm{EC})+\text { Straw } \\
\text { mulching }\end{array}$ & 283.00 & 32.67 & 42.81 & 81.28 & 12.72 \\
\hline $\mathrm{T}_{4}$ & $\begin{array}{c}\text { Pendimethalin (30 EC) + } \\
\text { (Chlorimuron 10\% WP + } \\
\text { Metsulfuronmethyl 10\% WP) }\end{array}$ & 285.67 & 21.33 & 33.20 & 85.46 & 13.20 \\
\hline $\mathrm{T}_{5}$ & $\begin{array}{c}\text { Butachlor }(50 \mathrm{EC})+\text { Bispyribac } \\
\text { sodium }(10 \% \mathrm{SC})\end{array}$ & 267.67 & 13.00 & 22.59 & 90.15 & 8.35 \\
\hline $\mathrm{T}_{6}$ & $\begin{array}{c}\text { Butachlor }(50 \mathrm{EC})+2,4-\mathrm{D}(\mathrm{SS}) \\
(80 \mathrm{WP})\end{array}$ & 292.00 & 25.33 & 36.59 & 84.15 & 11.85 \\
\hline $\mathrm{T}_{7}$ & $\begin{array}{l}\text { Butachlor (50EC) + Straw } \\
\text { mulching }\end{array}$ & 298.33 & 33.33 & 45.49 & 80.14 & 13.63 \\
\hline $\mathrm{T}_{8}$ & Mechanical weeding & 302.33 & 37.33 & 49.74 & 61.58 & 14.72 \\
\hline $\mathrm{T}_{9}$ & Need based hand weeding & 315.00 & 11.00 & 17.33 & 92.44 & 0.00 \\
\hline \multirow[t]{3}{*}{$\mathrm{T}_{10}$} & Unweeded control & 526.00 & 549.67 & 228.77 & 0.00 & 44.82 \\
\hline & S.Em \pm & 1.93 & 2.00 & 0.38 & 4.57 & 0.16 \\
\hline & C.D. $(\mathrm{P}=0.05)$ & 5.61 & 5.76 & 1.10 & 13.25 & 0.48 \\
\hline
\end{tabular}


Table. 2 Growth, yield parameters, yield and economical gains from aerobic rice as influenced by weed control treatments

\begin{tabular}{|c|c|c|c|c|c|c|c|c|c|c|c|c|}
\hline $\begin{array}{l}\text { Tr. } \\
\text { No. }\end{array}$ & Treatments & $\begin{array}{c}\text { Plant } \\
\text { populatio } \\
\mathrm{n} / \mathrm{m}^{2} \text { (At } \\
\text { maturity) }\end{array}$ & $\begin{array}{c}\text { Plant } \\
\text { height } \\
(\mathrm{cm})(\mathrm{At} \\
\text { harvest) }\end{array}$ & $\begin{array}{l}\text { Tillers/m } \\
{ }^{2} \text { (At } \\
\text { harvest) }\end{array}$ & $\begin{array}{l}\text { Panicle } \\
\mathrm{s} / \mathrm{m}^{2}\end{array}$ & $\begin{array}{c}\text { Number } \\
\text { of filled } \\
\text { grains/pan } \\
\text { icle }\end{array}$ & $\begin{array}{l}\text { Test } \\
\text { weigh } \\
\mathrm{t}(\mathrm{g})\end{array}$ & $\begin{array}{l}\text { Grain } \\
\text { yield } \\
\text { (kg/ha) }\end{array}$ & $\begin{array}{l}\text { Straw } \\
\text { yield } \\
(\mathrm{kg} / \mathrm{ha})\end{array}$ & $\begin{array}{c}\text { Harvest } \\
\text { index } \\
(\%)\end{array}$ & $\begin{array}{l}\text { Net } \\
\text { income } \\
\text { (Rs./ha) }\end{array}$ & $\begin{array}{l}\mathrm{B}: \mathrm{C} \\
\text { ratio }\end{array}$ \\
\hline $\mathrm{T}_{1}$ & $\begin{array}{l}\text { Pendimethalin (30 } \\
\text { EC) + Bispyribac } \\
\text { sodium }(10 \% \text { SC) }\end{array}$ & 46.54 & 85.77 & 352.50 & 254.90 & 119.10 & 23.73 & 4899.77 & 11957.69 & 28.77 & 55163 & 3.40 \\
\hline $\mathrm{T}_{2}$ & $\begin{array}{c}\text { Pendimethalin (30 } \\
\text { EC) + 2,4-D (SS) } \\
(80 \mathrm{WP})\end{array}$ & 44.46 & 84.67 & 346.17 & 237.77 & 116.63 & 23.67 & 4420.00 & 10986.09 & 28.69 & 49438 & 3.33 \\
\hline $\mathrm{T}_{3}$ & $\begin{array}{c}\text { Pendimethalin (30 } \\
\text { EC) + Straw } \\
\text { mulching }\end{array}$ & 43.49 & 84.50 & 347.40 & 244.42 & 109.87 & 23.68 & 4360.00 & 10712.69 & 28.93 & 48380 & 3.28 \\
\hline $\mathrm{T} 4$ & $\begin{array}{l}\text { Pendimethalin (30 } \\
\text { EC) + } \\
\text { (Chlorimuron } \\
10 \% \text { WP + } \\
\text { Metsulfuronmethy } \\
110 \% \mathrm{WP})\end{array}$ & 45.92 & 84.93 & 345.20 & 248.50 & 105.60 & 23.71 & 4450.00 & 10967.49 & 28.86 & 49475 & 3.29 \\
\hline $\mathrm{T} 5$ & $\begin{array}{c}\text { Butachlor }(50 \mathrm{EC}) \\
+ \text { Bispyribac } \\
\text { sodium }(10 \% \mathrm{SC})\end{array}$ & 46.98 & 84.25 & 355.93 & 252.50 & 121.40 & 23.75 & 4946.93 & 12223.33 & 28.81 & 56485 & 3.51 \\
\hline T6 & $\begin{array}{l}\text { Butachlor (50EC) } \\
+2,4-\mathrm{D}(\mathrm{SS}) \\
\text { (80WP) }\end{array}$ & 44.59 & 85.47 & 341.60 & 239.50 & 113.80 & 23.68 & 4410.00 & 10936.23 & 28.74 & 49673 & 3.39 \\
\hline $\mathrm{T}_{7}$ & $\begin{array}{l}\text { Butachlor (50EC) } \\
+ \text { Straw mulching }\end{array}$ & 43.67 & 84.52 & 348.33 & 242.10 & 102.78 & 23.69 & 4390.00 & 11004.47 & 28.52 & 49497 & 3.38 \\
\hline $\mathrm{T}_{8}$ & $\begin{array}{l}\text { Mechanical } \\
\text { weeding }\end{array}$ & 45.67 & 86.02 & 349.53 & 246.43 & 107.25 & 23.70 & 4723.00 & 12449.75 & 27.50 & 52339 & 3.19 \\
\hline $\mathrm{T}_{9}$ & $\begin{array}{l}\text { Need based hand } \\
\text { weeding }\end{array}$ & 48.30 & 87.11 & 357.20 & 256.80 & 125.47 & 23.96 & 5300.00 & 12910.24 & 29.11 & 53338 & 2.71 \\
\hline \multirow[t]{3}{*}{$\mathrm{T}_{10}$} & Unweeded control & 30.20 & 68.03 & 137.00 & 117.67 & 66.03 & 23.04 & 2123.46 & 5589.71 & 27.53 & 14385 & 1.72 \\
\hline & S.Em \pm & 0.37 & 0.28 & 1.28 & 1.20 & 0.51 & 0.22 & 15.55 & 39.12 & 0.16 & - & - \\
\hline & C.D. $(\mathrm{P}=0.05)$ & 1.07 & 0.80 & 3.73 & 3.47 & 1.47 & 0.67 & 45.12 & 113.53 & 0.46 & - & - \\
\hline
\end{tabular}

\section{Effect on crop}

The plant height 30 DAS stage ranged from $27.92 \mathrm{~cm}$ to $32.16 \mathrm{~cm}$, whereas at harvest stage, $68.03 \mathrm{~cm}$ to $87.11 \mathrm{~cm}$ height in different treatments. The number of tillers $/ \mathrm{m}^{2}$, ranged from 84.67 to $115.60 / \mathrm{m}^{2}$ at $30 \mathrm{DAS}$, whereas at the harvest stage, tillers were 137 to $357.20 / \mathrm{m}^{2}$ under different treatments.

As regards with the treatments effect, the plant height and tillers $/ \mathrm{m}^{2}$ were significantly higher in case of $T_{1}$ to $T_{9}$ treatments over $T_{10}$ (unweeded control) at every stage of observations. Out of weed control treatments, $\mathrm{T}_{9}$ (hand weeding twice) recorded maximum plant height (87.11 $\mathrm{cm})$ and tillers $/ \mathrm{m}^{2}\left(357.20 / \mathrm{m}^{2}\right)$. This was closely followed by $\mathrm{T}_{5}$ (Butachlor @ $1.5 \mathrm{~kg}$ a.i./ha + Bispyribac sodium @ 35 g.a.i/ha), $\mathrm{T}_{1}$ (Pendimethalin@1.00 kg a.i./ha + Bispyribac sodium @35 g.a.i/ha) and then $\mathrm{T}_{8}$ (mechanical weeding twice). The treatments $T_{3}$ and $T_{7}$ having straw mulching with Pendimethalin and Butachlor at 1.00 and $1.5 \mathrm{~kg}$ a.i./ha were also found equally effective with respect to both the growth parameters. The treatments $T_{1}$ and $T_{5}$ having Pendimethalin and Butachlor along with Bispyribac sodium were found comparable to that of mechanical or hand weeding twice $\left(\mathrm{T}_{8}\right.$ and $\mathrm{T}_{9}$ ) (Table 2).

Amongst the weed control treatments, HW $\left(\mathrm{T}_{9}\right)$ treatment resulted in maximum panicles $\left(256.80 / \mathrm{m}^{2}\right)$, grains/panicle (125.47) and 1000grain weight $(23.96 \mathrm{~g})$. This was closely followed by $\mathrm{T}_{5}$ (Butachlor @ $1.5 \mathrm{~kg}$ a.i./ha + Bispyribac sodium @ 35 g.a.i/ha) and $\mathrm{T}_{1}$ (Pendimethalin@1.00 kg a.i./ha + Bispyribac sodium @ 35 g.a.i/ha) The treatments $\mathrm{T}_{1}$ and $\mathrm{T}_{5}$ were found to be equally effective and comparable with that of HW twice $\left(\mathrm{T}_{9}\right)$. Weeding by hand-weeder twice $\left(\mathrm{T}_{8}\right)$ also 
proved equally better in increasing yield attributing as in case of $\mathrm{T}_{1}, \mathrm{~T}_{2}, \mathrm{~T}_{5}, \mathrm{~T}_{6}$ and $\mathrm{T}_{9}$ treatments. All the treatments $\left(\mathrm{T}_{1}\right.$ to $\left.\mathrm{T}_{9}\right)$ proved significantly superior to $\mathrm{T}_{10}$ (unweeded control).

Amongst the weed control treatments, $\mathrm{T}_{9}(\mathrm{HW}$ twice) gave significantly higher grain yield $(5300 \mathrm{~kg} / \mathrm{ha})$ in comparison to all other treatments. This was followed by $\mathrm{T}_{5}$ (Butachlor @ $1.5 \mathrm{~kg}$ a.i./ha + Bispyribac sodium @ 35 g.a.i/ha) and $\mathrm{T}_{1}$ (Pendimethalin @ $1.00 \mathrm{~kg}$ a.i./ha + Bispyribac sodium @ 35 g.a.i/ha)

The treatments $T_{1}$ and $T_{5}$ were found to be equally effective and comparable with that of HW twice $\left(T_{9}\right)$. All the treatments $\left(T_{1}\right.$ to $\left.T_{9}\right)$ proved significantly superior to $\mathrm{T}_{10}$ (unweeded control).

All the weed control treatments ( $T_{1}$ to $T_{9}$ ) recorded almost significantly higher harvest index (28.52 to $29.11 \%$ ) over unweeded control $\mathrm{T}_{10}(27.53 \%)$ except $\left(\mathrm{T}_{8}\right)$ mechanical weeding twice (27.50). Amongst these nine treatments, $\mathrm{T}_{9}$ (HW twice) registered significantly higher harvest index $(29.11 \%)$.

Application of $\mathrm{T}_{5}$ (Butachlor @ $1.5 \mathrm{~kg}$ a.i. /ha + Bispyribac sodium @ 35 g.a.i/ha) treatment gave the maximum net income (Rs.56485/ha) and $\mathrm{B}$ : $\mathrm{C}$ ratio (3.51). The second best treatment was $\mathrm{T}_{1}$ (Pendimethalin@1.00 kg a.i. /ha + Bispyribac sodium@35 g a.i /ha) giving net income up to Rs.55163/ha with B: C ratio 3.40. The third best treatment was $\mathrm{T}_{6}$ (Butachlor @ $1.5 \mathrm{~kg}$ a.i. /ha + 2, 4- D $0.06 \mathrm{~kg}$ a.i./ha) which gave Rs.49673/ha with B:C ratio (3.39)) as compared to other treatments. The lowest net income (Rs.14385/ha) with B: C ratio 1.72 was recorded from $\mathrm{T}_{10}$ (unweeded control) treatment.

\section{References}

Azmi M and Baki B B. 2002. Impact of continuous direct seeding rice culture on weed species diversity in the Malaysian rice ecosystem. Regional Symposium on Environment and Natural Resources, Kuala Lumpur, Malaysia. 1: 61-67.

Bouman B A M, Peng S, Castaneda A R, and Visperas R M. 2005. Yield and water use of irrigated tropical aerobic rice system. Agricultural Water Management. 74: 87105.

Bouman B A M. 2001. Water efficient management strategies in rice production. International Rice Research Notes. 26(2): 17-22.

Guerra L C, Bhuiyan S I, Tuong T P, Barker R. 1998. Producing more rice with less water from irrigated systems. IWMI/IRRI, SWIM. 4: 25.

Jayadeva HM, Bhairappanavar ST, Hugar AY, Rangaswamy BR, Mallikarjun GB, Malle shappa C and Naik DC. 2011. Integrated Weed Management In Aerobic Rice (Oryza Sativa L.) Agricultural Science Digest - A Research Journal. 31(1):5861.

Mishra J S and Singh V P. 2007. Integrated weed management in dry seeded irrigated rice. Indian Journal of Agronomy. 53(4): 299.

Sunil C M, Kalyanamurthy K N and Shankaralingappa B C. 2010. Indian Journal of Weed Sciences. 42(3\&4):180183.

Swanton C J and Weise S F. 1991. Integrated weed management: the rationale and approach. Weed Technology, (5):657663.

\section{How to cite this article:}

Vaishali Yadav, R.K. Tiwari, Punit Tiwari and Jyoti Tiwari. 2018. Integrated Weed Management in Aerobic Rice (Oryza sativa L.). Int.J.Curr.Microbiol.App.Sci. 7(01): 3099-3104. doi: https://doi.org/10.20546/ijcmas.2018.701.367 